\title{
PENGARUH KEPRIBADIAN WIRAUSAHA, PENGETAHUAN KEWIRAUSAHAAN, DAN LINGKUNGAN TERHADAP MINAT BERWIRAUSAHA SISWA SMK
}

\author{
Eka Aprilianty \\ SMK Muhammadiyah Pangkalan Bun, Kalimantan Tengah \\ ty.lian@ymail.com
}

\begin{abstract}
ABSTRAK
Abtrak: Pengaruh Kepribadian Wirausaha, Pengetahuan Kewirausahaan, dan Lingkungan terhadap Minta Berwirausaha Siswa SMK. Tujuan penelitian untuk mengungkapkan pengaruh potensi kepribadian wirausaha, pengetahuan kewirausahaan, dan lingkungan keluarga terhadap minat berwirausaha. Penelitian menggunakan pendekatan ex post facto. Populasi adalah siswa SMK Rumpun Pertanian di Daerah Istimewa Yogyakarta. Sampel sebanyak 113 responden ditentukan menggunakan teknik proportional random sampling. Data dikumpulkan dengan instrumen angket dan tes. Analisis data menggunakan statistik deskriptif dan statistik inferensia. Penelitian menunjukkan minat berwirausaha relatif rendah $(48,67 \%)$, potensi kepribadian wirausaha memberi pengaruh cukup berarti terhadap minat berwirausaha (27,3\%), pengetahuan kewirausahaan berpengaruh berarti terhadap minat berwirausaha $(13,7 \%)$, lingkungan keluarga memberi pengaruh yang berarti terhadap minat berwirausaha (22\%). Terdapat pengaruh secara bersama-sama antara potensi kepribadian wirausaha, pengetahuan kewirausahaan, dan lingkungan keluarga sebesar 42,2 persen terhadap minat berwirausaha.
\end{abstract}

Kata kunci: minat berwirausaha

\section{THE EFFECT OF ENTREPRENEUR PERSONALITY, ENTREPRENEURSHIP KNOWLEDGE, AND ENVIRONMENT ON ENTREPRENEURIAL INTEREST OF VOCATIONAL HIGH SCHOOL STUDENTS}

\begin{abstract}
The Effect of Potential Entrepreneur Personality, Entrepreneurship Knowledge, and Environment on Entrepreneurial Interest of Vocational High School Students. The purposes of this research are to reveal the effect of potential entrepreneur personality, entrepreneurship knowledge, and environment on the entrepreneurial interest. This study uses the ex post facto approach. The population is Agriculture vocational high school students in Daerah Istimewa Yogyakarta. A sample of 113 respondents is established using the proportional random sampling technique. The data are collected using questionnaires and a test. The data are analyzed using descriptive statistics and statistical inference. The results show that almost half (48.67) of students have a low entrepreneurial interest. The results also show that potential entrepreneur personality gives a positive and significant effect on entrepreneurial interest (27.3\%). Entrepreneurship knowledge has a significant positive effect on entrepreneurial interest (13.7\%). Family environment has a significant positive effect on entrepreneurial interest (22\%). The potential entrepreneur personality, entrepreneurship knowledge, and family environment collectively have the effect of 42.2 percent on the entrepreneurial interest.
\end{abstract}

Keywords: entrepreneurial interest 


\section{PENDAHULUAN}

Pengangguran dan kemiskinan masih menjadi permasalahan di Indonesia. Pengangguran dan kemiskinan terjadi karena perbandingan antara jumlah penawaran kesempatan kerja tidak sebanding dengan jumlah lulusan atau penawaran tenaga kerja baru di segala level pendidikan (Saiman, 2009: 22). Data statistik pada Pebruari 2011 yaitu sebanyak 8,12 juta orang dengan tingkat pengangguran terbuka sebesar 6,80 persen (Badan Pusat Statistik RI, 2011) menunjukkan jumlah pengangguran masih relatif tinggi. Namun, jumlah pengangguran dan kemiskinan sebenarnya dapat diperkecil dengan keberanian membuka usaha-usaha baru atau berwirausaha.

Dalam rangka meningkatkan pembangunan ekonomi, khususnya pengembangan kewirausahaan di seluruh tanah air, Presiden Susilo Bambang Yudhoyono telah mencanangkan Gerakan Kewirausahaan Nasional (GKN) pada Pebruari 2011. Dengan adanya GKN diharapkan generasi muda memiliki minat untuk menjadi wirausahawan.

An interest can be defined as something that arouses or holds one's attention or curiosity. Interests are indications of what individuals want to do or what they enjoy or like" (Brown \& Brooks, 1990: 82).

Minat dapat didefinisikan sebagai sesuatu yang membangkitkan perhatian pada suatu hal. Minat mengindikasikan apa yang diinginkan atau dilakukan orang atau apa yang mereka senangi. Seseorang yang berminat pada suatu hal, maka segala tindakan atau apa yang dilakukan akan mengarahkannya pada minatnya tersebut.

Minat berwirausaha di Indonesia masih sangat rendah. Jumlah wirausahawan di Indonesia baru 0,18 persen dari jumlah penduduk, masih jauh di bawah negara lain yaitu dibandingkan dengan Malaysia yang sudah 2 persen, Amerika 4 persen, dan Singapura 7 persen. Suatu negara akan maju dan stabil perekonomiannya jika penduduk yang menjadi wirausahawan minimal 2 persen dari jumlah penduduk (www.jpnn.com).

... many people, still, do not consider entrepreneurship as a career" (Hisrich et al., 2005: 18).

Sekolah Menengah Kejuruan (SMK) mempunyai peluang yang cukup besar untuk ikut serta dalam membangun sistem perekonomian dengan memanfaatkan tahap perkembangan remaja, mendidik siswa agar berminat menjadi wirausaha. Tahap perkembangan remaja akhir ditandai dengan adanya minat yang makin mantap terhadap fungsi-fungsi intelek (Sarwono, 2011: 30). Menurut Mappiare (1982: 88) “... jenis pekerjaan/jabatan yang dipilih oleh seorang remaja akhir dipengaruhi oleh minat ...”. Minat berwirausaha yang muncul diharapkan akan membentuk kecenderungan membuka usahausaha baru secara mandiri di masa mendatang.

"Kewirausahaan adalah suatu cara berpikir, menelaah, dan bertindak yang didasarkan pada peluang bisnis, pendekatan holistik, dan kepemimpinan yang seimbang" (Timmons \& Spinelli, 2004: 31). Proses kewirausahaan menuntut kemauan untuk mengambil resiko dengan penuh perhitungan sehingga dapat mengatasi rintangan untuk mencapai kesuksesan yang diharapkan. Pada umumnya, wirausahawan menggunakan kecerdikannya untuk memanfaatkan sumberdaya yang terbatas. 
...entrepreneur is one who develops a new product or new idea and builds a business around the new concept" (Lambing \& Kuehl, 2000: 14).

Wirausahawan adalah seseorang yang mengembangkan produk baru atau ide baru dan membangun bisnis dengan konsep baru. Dalam hal ini, menuntut sejumlah kreativitas dan sebuah kemampuan untuk melihat pola-pola dan trend-trend yang berlaku untuk menjadi seorang wirausahawan. Namun, masih banyak yang kurang kreatif dan tidak berani mengambil resiko untuk membuka dan mengelola usaha. Kreatif dan keberanian mengambil resiko merupakan kepribadian wirausaha. Beberapa kepribadian wirausaha lainnya seperti percaya diri, berorientasi pada hasil, kepemimpinan, kerja keras, dan masih banyak lagi, akan mendukung terbentuknya sumberdaya manusia yang mampu mengelola usaha.

Wirausahawan yang berhasil, salah satu kuncinya memiliki kepribadian yang unggul. Kepribadian tersebut kadangkala membedakannya dari kebanyakan orang. Gambaran ideal seorang wirausahawan menurut Alma (2010: 21) adalah orang yang dalam keadaan bagaimanapun daruratnya, tetap mampu berdiri atas kemampuan sendiri untuk menolong dirinya keluar dari kesulitan yang dihadapi, termasuk mengatasi kemiskinan tanpa bantuan siapapun. Bahkan dalam keadaan yang biasa (tidak darurat), mampu menjadikan dirinya maju, kaya, berhasil lahir dan bathin. Oleh karena itu, hendaknya siswa SMK memiliki potensi kepribadian wirausaha agar kelak mampu mandiri, menolong dirinya sendiri dalam menghadapi kesulitan hidup, bahkan mampu membuka peluang kerja bagi dirinya dan orang lain.
Linan \&. Leon (2007) berpendapat

the individual's decision to become an entrepreneur is sometimes assumed to depend on personality traits: "If you have the proper personality profile, you will become an entrepreneur sooner or later".

Menurut Alma (2010: 12) yang paling mendorong seseorang untuk memasuki karir wirausaha adalah adanya (1) personal attributes dan (2) personal environment. Hasil-hasil penelitian menyebutkan bahwa minat berwirausaha dipengaruhi oleh potensi kepribadian wirausaha dan lingkungan.

Kewirausahaan dapat diajarkan melalui pendidikan dan pelatihan. “... entrepreneurship has models, processes, and case studies that allow the topic to be studied and the knowledge to be acquired" (Kuratko \& Hodgetts, 2007: 34). Realita di lapangan, sistem pembelajaran saat ini belum sepenuhnya secara efektif membangun peserta didik memiliki akhlak mulia dan karakter bangsa termasuk karakter wirausaha. Proses pembelajaran di SMK belum sepenuhnya mampu membangun potensi kepribadian wirausaha. Hal ini antara lain ditunjukkan dengan jumlah pengangguran yang relatif tinggi, jumlah wirausaha yang masih relatif sedikit, dan terjadinya degradasi moral (Kemendiknas, 2010).

Pembekalan pengetahuan kewirausahaan kepada siswa-siswa SMK sangat perlu dilakukan. Semakin tinggi pengetahuan kewirausahaan siswa SMK akan semakin terbuka wawasannya tentang kewirausahaan. Hasil-hasil penelitian menyimpulkan bahwa pengetahun kewirausahaan berpengaruh terhadap minat berwirausaha. Sekolah idealnya dapat membantu pembentukan minat siswa berwirausaha. Namun, masih banyak SMK 
hanya menitikberatkan pembelajaran pada aspek pengetahuan saja dan belum mampu mengkondisikan lingkungan sekolah yang dapat menumbuhkan minat siswa berwirausaha. Proses pembelajaran yang selama ini hanya dititikberatkan pada aspek pengetahuan semestinya diikuti dengan pembelajaran keterampilan wirausaha di lapangan.

Peran keluarga juga sangat penting dalam menumbuhkan minat berwirausaha bagi para siswa. Pendidikan berwirausaha dapat berlangsung sejak usia dini dalam lingkungan keluarga.

Having a mother or father who is selfemployed provides a strong inspiration for the entrepreneur. The independent nature and flexibility of self-employment is ingrained at an early age" (Hisrich et al., 2005: 65).

Memiliki seorang ibu dan ayah yang berwirausaha memberikan inspirasi kepada anak untuk menjadi wirausahawan. Fleksibilitas dan kemandirian dari wirausahawan telah mendarah daging pada anak sejak dini. Anak terinspirasi untuk berwirausaha karena melihat kesungguhan dan kerja keras ayah dan ibunya atau orangtuanya berusaha dalam bidang pertanian yang menghasilkan keuntungan. Anak juga terinspirasi karena memang dilatih sejak kecil, diminta membantu mulai dari pekerjaan yang ringan atau mudah sampai yang rumit dan komplek. Terlatih dan terinspirasi sehingga mempengaruhi minatnya dalam berwirausaha di bidang pertanian. Melalui keluarga pola pikir kewirausahaan terbentuk. Minat berwirausaha tumbuh dan berkembang dengan baik pada seseorang yang hidup dan tumbuh di lingkungan keluarga wirausahawan. Kenyataannya, sebagian besar lingkungan keluarga belum kondusif dalam pembentukan minat anak dalam berwirausaha. Hal ini disebabkan oleh banyak faktor, antara lain: keterbatasan pengetahuan orangtua, pola pikir dalam keluarga menjadi PNS atau karyawan lebih aman daripada menjadi wirausahawan, tidak ada model wirausahawan dalam keluarga, dan lain sebagainya.

Wirausaha di bidang pertanian sifatnya unik dan memerlukan penanganan yang lebih khusus karena produk-produk yang dihasilkan berhubungan dengan prinsip dasar dalam menjalankan bisnis yang dipengaruhi oleh karakteristiknya. Adapun karakteristik usaha di bidang pertanian (Downey \& Erickson, 1992), antara lain: (1) keanekaragaman jenis bisnis yang sangat besar pada sektor pertanian yaitu dari produsen dasar, pengirim, perantara, pedagang borongan, pemroses, pengepak, pembuat barang, usaha pergudangan, pengangkutan, lembaga keuangan, pengecer, kongsi, bahan pangan, restoran-daftar ini hampir tidak ada akhirnya; (2) cara pembentukan usaha pertanian di sekeliling pengusaha tani. Para pengusaha tani ini menghasilkan bahan pangan dan sandang yang merupakan bahan baku usaha pertanian; (3) keanekaragaman dalam hal ukuran usaha pertanian, dari perusahaan raksasa sampai yang dikelola oleh satu orang atau satu keluarga; (4) falsafah hidup tradisional yang dianut para pekerja bidang pertanian cenderung membuat usaha pertanian lebih kolot dibanding bisnis lainnya; (5) kenyataan bahwa badan usaha bidang pertanian cenderung berorientasi pada keluarga. Suami dan istri sering sangat terlibat baik pada tahap pengoperasian maupun tahap pengambilan keputusan bisnis berdasarkan mitra 
kerja penuh (full-parnership); (6) kenyataan bahwa usaha pertanian cenderung berorientasi pada masyarakat. Banyak diantaranya berlokasi di kota kecil dan daerah pedesaan dimana hubungan antar-perorangan penting dan ikatan bersifat jangka panjang; (7) kenyataan bahwa usaha pertanian, bahkan yang sudah menjadi industri besar sekalipun sangat bersifat musiman; (8) usaha pertanian berhubungan pula dengan gejala alam. Kekeringan, banjir, hama, dan penyakit merupakan ancaman yang tetap terhadap usaha pertanian; (9) dampak program dan kebijakan pemerintah mengena langsung kepada usaha bidang pertanian.

Berdasarkan hasil survey, lulusan SMK Rumpun Pertanian di Daerah Istimewa Yogyakarta, selain melanjutkan ke perguruan tinggi, rata-rata bekerja menjadi karyawan perusahaan perkebunan dan instansi pemerintah. Bahkan ada juga yang bekerja tidak sesuai dengan latar belakang pendidikannya yaitu pertanian, seperti bekerja di toko, di bengkel, menjadi ojek, supir, tenaga kerja yang bekerja di luar negeri, dan banyak pula yang masih menganggur. Adapun lulusan yang berwirausaha, sebagian juga tidak sesuai dengan latar belakang pendidikan yaitu pertanian. Dari gambaran sementara ini, dapatlah dikatakan, belum banyak lulusan SMK rumpun pertanian memilih karir wirausaha apalagi wirausaha di bidang pertanian. Sehingga sangat perlu dikaji apakah siswa SMK rumpun pertanian di Daerah Istimewa Yogyakarta masih banyak yang belum berminat memilih karir sebagai wirausahawan. Padahal peluang untuk menjadi wirausahawan di bidang pertanian cukup luas, dari sektor hulu hingga hilir. Wirausaha bidang pertanian dapat dilakukan mulai dari penyediaan sarana produksi, proses produksi, penanganan pasca panen dan pengolahan hasil, serta pemasaran.

Menurut Brown dan Brooks (1990: 3) bahwa proses memilih karir diawali dengan minat terhadap karir tersebut dan hal ini dapat diketahui melalui pendekatan ilmiah. Oleh karena itu, penelitian dilakukan dengan tujuan untuk mengungkapkan:

1. Pengaruh potensi kepribadian wirausaha terhadap minat berwirausaha siswa SMK Rumpun Pertanian di Daerah Istimewa Yogyakarta.

2. Pengaruh pengetahuan kewirausahaan terhadap minat berwirausaha siswa SMK Rumpun Pertanian di Daerah Istimewa Yogyakarta.

3. Pengaruh lingkungan keluarga terhadap minat berwirausaha siswa SMK Rumpun Pertanian di Daerah Istimewa Yogyakarta.

4. Pengaruh potensi kepribadian wirausaha, pengetahuan kewirausahaan, dan lingkungan keluarga secara bersama-sama terhadap minat berwirausaha siswa SMK Rumpun Pertanian di Daerah Istimewa Yogyakarta.

\section{METODE}

Jenis penelitian yang digunakan adalah ex post facto. Penelitian telah dilaksanakan di SMK Rumpun Pertanian di Daerah Istimewa Yogyakarta, yaitu SMK Negeri 1 Nanggulan Kulon Progo, SMK Negeri 1 Pandak Bantul, SMK Indonesia YIPK Bantul, dan SMK Perkebunan MM 52 Kota Yogyakarta. Populasi berjumlah 157 orang dan sampel penelitian sebanyak 113 orang yang ditentukan dengan teknik proportional random sampling. 
Variabel dalam penelitian ini terdiri dari tiga variabel bebas (independent variable). Variabel tersebut diberi simbol X1, X2 dan X3, yaitu Potensi Kepribadian Wirausaha, Pengetahuan Kewirausahaan, dan Lingkungan Keluarga. Variabel terikat (dependent variable) diberi simbol Y yaitu Minat Berwirausaha. Data variabel $\mathrm{Y}, \mathrm{X} 1$, dan $\mathrm{X} 3$ dikumpulkan menggunakan instrumen kuesioner (angket). Skala yang digunakan dalam mengukur aspek ini adalah skala Likert dengan empat alternatif jawaban. Data variabel X2 menggunakan tes objektif bentuk pilihan ganda. Validitas angket digunakan teknik korelasi Product Moment dari Carl Pearson dan reliabilitasnya dianalisis menggunakan Alfa Cronbach's. Sedangkan instrumen tes pengujian validitasnya menggunakan teknik korelasi point biserial $\left(\mathrm{r}_{\mathrm{pbi}}\right)$ dan reliabilitas instrumen tes dianalisis dengan pendekatan Single Test - Single Trial menggunakan Formula C. Hoyt.

Teknik analisis data dalam penelitian ini menggunakan statistik deskriptif dan statistik inferensia. Untuk mendeskripsikan data digunakan kategorisasi menurut Mardapi (2004: 117). Pembagian empat kategori dimana $\mathrm{M}=$ skor rerata dan $\mathrm{SB}=$ simpangan baku adalah sebagai berikut.
Tabel 1. Pembagian empat kategorri

\begin{tabular}{|c|c|}
\hline $\mathrm{X} \geq(\mathrm{M}+1 \mathrm{SB})$ & $=$ sangat tinggi \\
\hline$(\mathrm{M}+1 \mathrm{SB})>\mathrm{X} \geq(\mathrm{M})$ & $=$ tinggi \\
\hline$(\mathrm{M})>\mathrm{X} \geq(\mathrm{M}-1 \mathrm{SB})$ & $=$ rendah \\
\hline $\mathrm{X}<(\mathrm{M}-1 \mathrm{SB})$ & $=$ sangat rendah \\
\hline
\end{tabular}

Dalam penelitian ini diuji tiga asumsi, yaitu normalitas, homoskedastisitas, dan multikolinieritas. Pengujian hipotesis menggunakan analisis regresi ganda. Sebagai kriteria penerimaan dan penolakan digunakan tingkat signifikansi 5\%. Untuk mengetahui korelasi dan besarnya pengaruh masing-masing variabel bebas terhadap variabel terikat digunakan analisis regresi sederhana.

\section{HASIL PENELITIAN DAN PEMBAHASAN}

\section{Deskripsi Data}

Hasil perhitungan melalui statistik deskriptif minat berwirausaha, potensi kepribadian wirausaha, pengetahuan kewirausahaan, dan lingkungan keluarga Siswa SMK Rumpun Pertanian di Daerah Istimewa Yogyakarta disajikan pada Tabel 2 dan Gambar 1.

Tabel 2. Distribusi Minat Berwirausaha (Y), Potensi Kepribadian Wirausaha (X1), Pengetahuan Kewirausahaan (X2), dan Lingkungan Keluarga (X3) Siswa SMK Rumpun Pertanian di DIY

\begin{tabular}{llcccccccc}
\hline \hline \multirow{2}{*}{ NO } & \multirow{2}{*}{ Kategori } & \multicolumn{2}{c}{ Y } & \multicolumn{2}{c}{ X1 } & \multicolumn{2}{c}{ X2 } & \multicolumn{2}{c}{ X3 } \\
\cline { 3 - 10 } & & Frek. & \% & Frek. & \% & Frek. & \% & Frek. & \% \\
\hline \hline 1 & Sangat tinggi & 15 & 13,27 & 18 & 15,93 & 6 & 5,31 & 12 & 10,62 \\
2 & Tinggi & 29 & 25,66 & 31 & 27,43 & 74 & 65,49 & 34 & 30,09 \\
3 & Rendah & 55 & 48,67 & 46 & 40,71 & 21 & 18,58 & 46 & 40,71 \\
4 & Sangat rendah & 14 & 12,4 & 18 & 15,93 & 12 & 10,62 & 21 & 18,58 \\
\hline
\end{tabular}


Siswa sebagian besar memiliki kecenderungan minat berwirausaha dalam bidang pertanian yang masih rendah. sebanyak 55 orang atau $48,67 \%$ dari seluruh responden pada kategori rendah. Minat berwirausaha pada kategori tinggi hanya dicapai oleh 29 orang responden atau $25,66 \%$ dari seluruh responden. Sementara kategori minat berwirausaha di bidang pertanian sangat tinggi dan sangat rendah cenderung sebanding masing-masing 15 orang $(13,27 \%)$ dan 14 orang $(12,40 \%)$ dari seluruh responden.

Potensi kepribadian wirausaha di bidang pertanian siswa SMK Rumpun Pertanian di Daerah Istimewa Yogyakarta masih rendah. Hasil penelitian menunjukkan sebanyak 46 orang atau $40,71 \%$ dari seluruh responden potensi kepribadian wirausahanya berada pada kategori rendah. Potensi kepribadian wirausaha di bidang pertanian pada kategori tinggi hanya dicapai oleh 31 orang responden atau 27,43\% dari seluruh responden. Sedangkan potensi kepribadian wirausaha dengan kategori sangat tinggi dicapai oleh 18 orang responden atau $15,93 \%$ dari seluruh responden sebanding dengan potensi kepribadian wirausaha kategori sangat rendah.

Pengetahuan kewirausahaan di bidang pertanian siswa SMK Rumpun Pertanian di Daerah Istimewa Yogyakarta cukup tinggi. Hasil penelitian menunjukkan bahwa skor tertinggi sebanyak 74 orang atau $65,49 \%$ dari seluruh responden pengetahuan kewirausahaannya berada pada kategori tinggi. Sementara pengetahuan kewirausahaan di bidang pertanian 6 orang responden atau 5,31\% dari seluruh responden pada kategori sangat tinggi. Pengetahuan kewirausahaan pada kategori rendah dicapai oleh 21 orang responden atau $18,58 \%$ dari seluruh responden. Sedangkan pengetahuan kewirausahaan bidang pertanian kategori sangat rendah dicapai oleh 12 orang responden atau 10,62\% dari seluruh responden.

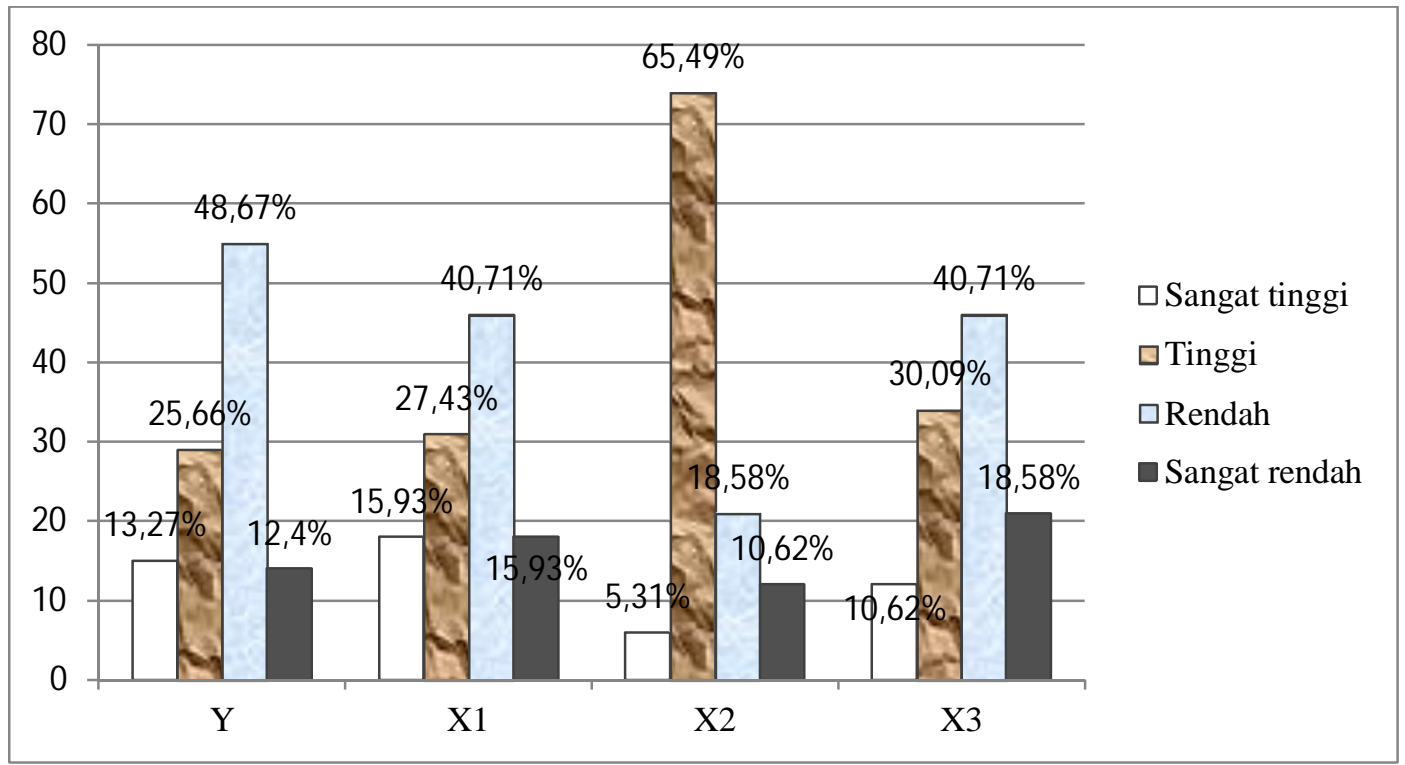

Gambar 1. Distribusi Minat Berwirausaha (Y), Potensi Kepribadian Wirausaha (X1), Pengetahuan Kewirausahaan (X2), dan Lingkungan Keluarga (X3) Siswa SMK Rumpun Pertanian di DIY 
Siswa SMK Rumpun Pertanian di Daerah Istimewa Yogyakarta memiliki dukungan lingkungan keluarga yang masih rendah pada minat berwirausaha siswa di bidang pertanian. Hasil penelitian menunjukkan sebanyak 46 orang atau 40,71\% dari seluruh responden dukungan lingkungan keluarga berada pada kategori rendah. Namun, kategori tinggi juga cukup banyak yaitu dicapai oleh 34 orang responden atau 30,09\% dari seluruh responden. Dukungan lingkungan keluarga sangat tinggi dicapai oleh 12 orang responden atau 10,62\% dari seluruh responden. Sedangkan 21 orang responden atau $18,58 \%$ dari seluruh responden memiliki dukungan lingkungan keluarga yang masih sangat rendah terhadap minat berwirausaha di bidang pertanian.

\section{Analisis Data}

\section{Uji Hipotesis Pertama}

Hipotesis pertama, terdapat pengaruh positif potensi kepribadian wirausaha terhadap minat berwirausaha. Tabel 2 merupakan hasil analisis regresi ganda yang menunjukkan koefisien regresi untuk potensi kepribadian wirausaha (X1) adalah 0,265 yang bernilai positif. Berarti Minat berwirausaha bidang pertanian akan meningkat apabila potensi kepribadian wirausaha ditingkatkan. Semakin tinggi potensi kepribadian wirausaha, semakin tinggi pula minat berwirausaha siswa di bidang pertanian. Nilai probabilitas pada kolom sig. adalah 0,000 , nilai $\mathrm{p}<0,05$ dapat diartikan bahwa pengaruh potensi kepribadian wirausaha terhadap minat berwirausaha di bidang pertanian signifikan. Sehingga dari hasil analisis regresi ganda dapat disimpulkan bahwa potensi kepribadian wirausaha memberi pengaruh positif dan signifikan terhadap minat berwirausaha. Dengan demikian, hipotesis pertama yang menyatakan terdapat pengaruh positif potensi kepribadian wirausaha terhadap minat berwirausaha terbukti.

Tabel 3. Rangkuman Nilai Koefisien dan Probabilitas Variabel X1, X2, dan X3

\begin{tabular}{lccccc}
\hline \hline \multirow{2}{*}{ Model } & \multicolumn{2}{c}{$\begin{array}{c}\text { Unstandarized } \\
\text { Coefficients }\end{array}$} & \multirow{2}{*}{$\mathrm{t}$} & sig \\
\cline { 2 - 3 } & $\mathrm{B}$ & Std. Error & & \\
\hline \hline Potensi Kepribadian Wirausaha & 0,265 & 0,052 & & 5,096 & 0,000 \\
Pengetahuan Kewirausahaan & 0,452 & 0,152 & 2,971 & 0,004 \\
Lingkungan Keluarga & 0,355 & 0,081 & & 4,385 & 0,000 \\
\hline
\end{tabular}

Korelasi dan kontribusi pengaruh potensi kepribadian wirausaha terhadap minat berwirausaha dapat diketahui dari hasil analisis regresi sederhana potensi kepribadian wirausaha terhadap minat berwirausaha. Hasil lengkapnya disajikan pada Tabel 4.
Pada tabel tersebut dapat diketahui besarnya koefisien korelasi (R) antara potensi kepribadian wirausaha dengan minat berwirausaha adalah 0,522. Dengan demikian berarti terdapat tingkat hubungan yang sedang antara potensi kepribadian wirausaha dengan minat berwirausaha di bidang pertanian. 
Berdasarkan Tabel 3, koefisien determinasi $\left(\mathrm{R}^{2}\right)$ adalah 0,273 . Hal ini berarti kontribusi pengaruh potensi kepribadian wirausaha terhadap minat berwirausaha di bidang pertanian sebesar 27,3\%.
Minat berwirausaha di bidang pertanian $27,3 \%$ ditentukan oleh potensi kepribadian wirausaha dan sebagian besar yaitu $72,7 \%$ dipengaruhi oleh variabel lain.

Tabel 4. Rangkuman Hasil Analisis Regresi Sederhana Variabel X1, X2, dan X3

\begin{tabular}{lcccc}
\hline \hline \multicolumn{1}{c}{ Model } & $\mathrm{R}$ & $\mathrm{R}$ Square & $\begin{array}{c}\text { Adjusted R } \\
\text { Square }\end{array}$ & $\begin{array}{c}\text { Std. Error of The } \\
\text { Estimate }\end{array}$ \\
\hline $\begin{array}{l}\text { Potensi Kepribadian } \\
\text { Wirausaha }\end{array}$ & 0,522 & 0,273 & 0,266 & 1,92237 \\
$\begin{array}{l}\text { Pengetahuan } \\
\text { Kewirausahaan }\end{array}$ & 0,370 & 0,137 & 0,129 & 2,09412 \\
\begin{tabular}{l} 
Lingkungan Keluarga \\
\hline
\end{tabular} & 0,470 & 0,220 & 0,213 & 1,99010 \\
\hline
\end{tabular}

\section{Uji Hipotesis Kedua}

Hipotesis kedua, terdapat pengaruh positif pengetahuan kewirausahaan terhadap minat berwirausaha. Tabel 2 menunjukkan koefisien regresi untuk pengetahuan kewirausahaan (X2) adalah 0,452 yang bernilai positif. Berarti Minat berwirausaha bidang pertanian akan meningkat apabila pengetahuan kewirausahaan ditingkatkan. Semakin tinggi pengetahuan kewirausahaan, semakin tinggi pula minat berwirausaha siswa di bidang pertanian. Nilai probabilitas pada kolom sig. adalah 0,000 , nilai $\mathrm{p}<0,05$ dapat diartikan bahwa pengaruh pengetahuan kewirausahaan terhadap minat berwirausaha di bidang pertanian signifikan. Sehingga dari hasil analisis regresi ganda dapat disimpulkan bahwa pengetahuan kewirausahaan memberi pengaruh positif dan signifikan terhadap minat berwirausaha. Dengan demikian hipotesis kedua yang menyatakan terdapat pengaruh positif pengetahuan kewirausahaan terhadap minat berwirausaha terbukti.

Korelasi dan kontribusi pengaruh pengetahuan kewirausahaan terhadap minat berwirausaha dapat diketahui dari hasil teknik analisis regresi sederhana pengetahuan kewirausahaan terhadap minat berwirausaha. Hasil lengkapnya disajikan pada Tabel 3.

Pada tabel tersebut dapat diketahui besarnya koefisien korelasi (R) antara pengetahuan kewirausahaan dengan minat berwirausaha adalah 0,370. Dengan demikian berarti terdapat tingkat hubungan yang rendah antara pengetahuan kewirausahaan dengan minat berwirausaha di bidang pertanian. Berdasarkan Tabel 3, koefisien determinasi $\left(\mathrm{R}^{2}\right)$ adalah 0,137 . Hal ini berarti kontribusi pengaruh pengetahuan kewirausahaan terhadap minat berwirausaha di bidang pertanian sebesar 13,7\%. Minat berwirausaha di bidang pertanian hanya $13,7 \%$ ditentukan oleh pengetahuan kewirausahaan, sedangkan $86,3 \%$ dipengaruhi oleh variabel lain.

\section{Uji Hipotesis Ketiga}

Hipotesis ketiga, terdapat pengaruh lingkungan keluarga terhadap minat berwirausaha. Tabel 2 menunjukkan koefisien regresi untuk lingkungan keluarga (X3) adalah 
0,355 yang bernilai positif. Berarti Minat berwirausaha bidang pertanian akan meningkat apabila dukungan lingkungan keluarga ditingkatkan. Semakin tinggi dukungan lingkungan keluarga, semakin tinggi pula minat berwirausaha siswa di bidang pertanian. Nilai probabilitas pada kolom sig. adalah 0,000 , nilai $\mathrm{p}<0,05$ dapat diartikan bahwa pengaruh lingkungan keluarga terhadap minat berwirausaha di bidang pertanian signifikan. Sehingga dari hasil analisis regresi ganda dapat disimpulkan bahwa lingkungan keluarga memberi pengaruh positif dan signifikan terhadap minat berwirausaha. Dengan demikian hipotesis ketiga yang menyatakan terdapat pengaruh positif lingkungan keluarga terhadap minat berwirausaha terbukti.

Korelasi dan kontribusi lingkungan keluarga terhadap minat berwirausaha dapat diketahui dari hasil teknik analisis regresi sederhana lingkungan keluarga terhadap minat berwirausaha. Hasil lengkapnya disajikan pada Tabel 3.

Pada tabel tersebut dapat diketahui besarnya koefisien korelasi (R) antara lingkungan keluarga dengan minat berwirausaha adalah 0,470 . Dengan demikian berarti terdapat tingkat hubungan yang sedang antara pengetahuan kewirausahaan dengan minat berwirausaha di bidang pertanian. Berdasarkan Tabel 3, koefisien determinasi $\left(\mathrm{R}^{2}\right)$ adalah 0,220. Hal ini berarti kontribusi pengaruh lingkungan keluarga terhadap minat berwirausaha di bidang pertanian sebesar $22 \%$. Minat berwirausaha di bidang pertanian $22 \%$ ditentukan oleh lingkungan keluarga, lebih kecil dibandingkan dengan pengaruh variabel lain yaitu $78 \%$.

\section{Uji Hipotesis Keempat}

Hipotesis keempat, terdapat pengaruh positif secara bersama-sama potensi kepribadian wirausaha, pengetahuan kewirausahaan, dan lingkungan keluarga terhadap minat berwirausaha. Tabel 4 merupakan hasil analisis regresi ganda yang menunjukkan koefisien korelasi (R) untuk potensi kepribadian wirausaha, pengetahuan kewirausahaan, dan lingkungan keluarga adalah 0,662. Berarti terdapat tingkat hubungan yang kuat antara potensi kepribadian wirausaha, pengetahuan kewirausahaan, dan lingkungan keluarga secara bersama-sama dengan minat berwirausaha di bidang pertanian. Nilai probabilitas pada kolom sig. adalah 0,000 , nilai $\mathrm{p}<0,05$ dapat diartikan bahwa pengaruh secara bersama-sama potensi kepribadian wirausaha, pengetahuan kewirausahaan, dan lingkungan keluarga terhadap minat berwirausaha di bidang pertanian signifikan. Sehingga dari hasil analisis regresi ganda dapat disimpulkan bahwa potensi kepribadian wirausaha, pengetahuan kewirausahaan, dan lingkungan keluarga secara bersama-sama memberi pengaruh positif dan signifikan terhadap minat berwirausaha. Dengan demikian hipotesis keempat terbukti, terdapat pengaruh positif dan signifikan potensi kepribadian wirausaha, pengetahuan kewirausahaan, dan lingkungan keluarga secara bersama-sama terhadap minat berwirausaha. 
Tabel 5. Rangkuman Hasil Analisis Regresi Ganda

\begin{tabular}{cccccc}
\hline \hline & $\mathrm{R}$ & $\mathrm{R}^{2}$ & Adjusted $^{2}$ & $\mathrm{~F}$ & $\mathrm{Sig}$ \\
\hline \hline Regresi & 0,662 & 0,438 & 0,422 & 28,299 & 0,000 \\
\hline
\end{tabular}

Dari analisis regresi ganda juga didapatkan besarnya kontribusi ketiga variabel bebas melalui nilai adjusted $\mathrm{R}^{2}$ sebesar 0,422 . Dengan demikian, dapat disimpulkan bahwa potensi kepribadian wirausaha, pengetahuan kewirausahaan, dan lingkungan keluarga secara bersama-sama memiliki pengaruh sebesar $42,2 \%$ terhadap minat berwirausaha siswa di bidang pertanian. Sebesar 42,2\% dari variasi skor minat berwirausaha dapat dijelaskan oleh kombinasi ketiga variabel tersebut. Sedangkan 57,8\% dipengaruhi oleh variabel lain yaitu variabelvariabel yang tidak diteliti dalam penelitian ini.

\section{PEMBAHASAN}

\section{Minat Berwirausaha}

Minat berwirausaha siswa yang masih rendah diduga terjadi akibat siswa sekarang tidak lagi tertarik pada bidang pertanian dan lebih memilih bidang lain. Hal ini karena sebagian besar siswa beranggapan bahwa pertanian adalah profesi yang kurang bergengsi. Siswa beranggapan bahwa pertanian adalah pekerjaan yang kasar, rendah, kurang keren karena pertanian berhubungan dengan cangkul, lumpur, dan dianggap hasilnya tidak menjanjikan. Padahal pertanian tidak melulu mencangkul tanah di tengah terik matahari. Melalui sistem hidroponik, misalnya, penyiraman tanaman dan perawatan seperti penyemprotan hama, bisa dilakukan secara otomatis. Selain itu, memproduksi produk olahan dengan cara modern dan dikemas apik menarik dapat menjadikan produk pertanian memiliki nilai tambah dan nilai jual yang tinggi. Sekolah kejuruan pertanian diharapkan dapat menyesuaikan perubahan zaman, mencitrakan pertanian modern yang menjanjikan kehidupan dan kesejahteraan, sehingga mampu menarik minat siswa dan mengembangkan kemandirian sekolah.

Cara pandang siswa akan arti penting pertanian kemungkinan juga merupakan implikasi dari berbagai kekeliruan pandangan secara nasional akibat masih kurangnya gaung kebijakan pertanian pemerintah, minimnya ekspos dari media mengenai kemajuan bidang pertanian dan prospek bidang pertanian, kurangnya informasi yang disampaikan oleh guru dan pihak sekolah, serta kepercayaan diri dari siswa sendiri. Kondisi tersebut juga sangatlah sesuai dengan kenyataan bahwa di masa sekarang banyak generasi muda yang tidak berminat berwirausaha. Rata-rata masih berkeinginan untuk menjadi karyawan baik di pemerintah maupun swasta. Wirausaha di bidang pertanian masih belum disadari sebagai usaha yang berpeluang besar.

Padahal negara Indonesia adalah negara agraris. Sektor pertanian merupakan penyedia pangan yang penting dalam menjaga stabilitas negara. Sektor pertanian mempunyai peranan yang sangat besar dalam menyumbang PDB nasional dan penyerapan tenaga kerja. Secara geografis negara Indonesia memiliki berbagai kelebihan jika dibandingkan negara-negara lain di dunia. Negara Indonesia memiliki jumlah 
radiasi sinar matahari sepanjang tahun. Suhu di Indonesia juga tidak terlalu panas dengan ketinggian wilayah ideal yang membuat pertumbuhan tanaman maksimal. Indonesia juga terletak di luar zona angin topan dan banyak penelitian yang menunjukkan adanya kelebihan daya tumbuh tanaman pada daerah beriklim tropis seperti Indonesia. Negara Indonesia juga mempunyai lahan yang cukup luas, merupakan potensi sangat besar yang tidak dimiliki oleh negara lain. Keanekaragaman jenis bisnis di bidang pertanian dari hulu ke hilir, dari penyediaan sarana produksi hingga pemasaran menunjukkan betapa peluang wirausaha di bidang pertanian cukup luas.

Berbagai kelebihan dan tantangan bidang pertanian mestinya menjadikan wirausaha pertanian sebagai pilihan utama siswa SMK rumpun pertanian. Ketika kemudian yang terjadi justru sebaliknya, maka perlu dicari penyebab terjadinya. Hasil penelitian juga menunjukkan sebanyak $25,66 \%$ responden memiliki minat yang tinggi untuk berwirausaha. Hasil ini memberikan gambaran bahwa yang tinggi minatnya untuk berwirausaha juga cukup banyak. Partisipasi segenap komponen untuk mengangkat kembali citra pertanian dan pendidikan pertanian diharapkan dapat meningkatkan minat berwirausaha di bidang pertanian generasi muda. Hal ini memerlukan perhatian yang sungguh-sungguh dan serius dari semua pihak baik kalangan orang tua, masyarakat, pendidik, maupun pemerintah.

\section{Potensi Kepribadian Wirausaha}

Potensi kepribadian wirausaha di bidang pertanian siswa SMK Rumpun Pertanian di Daerah Istimewa Yogyakarta masih rendah.
Adapun kontribusi pengaruh potensi kepribadian wirausaha terhadap minat berwirausaha sebesar 27,3\%. Potensi kepribadian wirausaha memberikan kontribusi yang lebih besar dari variabel-variabel lain dalam penelitian ini. Hal ini menunjukkan betapa pentingnya potensi kepribadian wirausaha dibangun, karena kenyataannya hasil penelitian menunjukkan bahwa potensi kepribadian wirausaha secara positif dan signifikan berpengaruh terhadap minat berwirausaha siswa.

Berbagai pihak perlu membantu siswa agar dapat menumbuhkan dan membangun potensi diri siswa. Percara diri, kreatif, berani mengambil resiko, berorientasi pada hasil, kepemimpinan, dan kerja keras perlu ditanamkan pada diri siswa. Sehingga siswa yang memiliki kepribadian tangguh semakin banyak. Jika semakin banyak yang memiliki potensi kepribadian wirausaha, semakin banyak pula yang berminat berwirausaha dan siap menjalani proses kewirausahaan.

\section{Pengetahuan Kewirausahaan}

Pengetahuan kewirausahaan di bidang pertanian siswa SMK Rumpun Pertanian di Daerah Istimewa Yogyakarta cukup tinggi. Hasil penelitian juga menunjukkan bahwa pengetahuan kewirausahan secara positif dan signifikan berpengaruh terhadap minat berwirausaha. Meskipun kontribusi pengetahuan kewirausahaan terhadap minat berwirausaha hanya sebesar $13,7 \%$, hendaknya pengetahuan kewirausahaan siswa ditindaklanjuti dengan kegiatan-kegiatan praktek kewirausahaan. Agar siswa tidak hanya memiliki pengetahuan tetapi juga memiliki keterampilan yang mendukung 
pengetahuannya tersebut. Sehingga minat siswa untuk berwirausaha akan semakin mantap.

\section{Lingkungan Keluarga}

Siswa SMK Rumpun Pertanian di Daerah Istimewa Yogyakarta memiliki dukungan lingkungan keluarga yang masih rendah pada minat berwirausaha siswa di bidang pertanian. Hasil penelitian juga menunjukkan bahwa lingkungan keluarga berpengaruh positif dan signifikan terhadap minat berwirausaha siswa dengan kontribusi pengaruh sebesar $22 \%$. Dukungan lingkungan keluarga pada kategori rendah dan minat berwirausaha siswa di bidang pertanian juga masih relatif rendah, namun pengaruhnya positif dan signifikan.

Sebagian besar usaha bidang pertanian masih bersifat subsisten, tradisional, hanya diusahakan untuk memenuhi keperluan keluarga tani. Usaha pertanian, sebagaimana salah satu karakteristiknya bersifat kolot dibandingkan bidang usaha lainnya. Sehingga usaha pertanian yang belum atau tidak sukses memberikan kesejahteraan kepada keluarga tani, dapat membuat minat anak terhadap wirausaha di bidang pertanian rendah. Hal ini juga menunjukkan betapa pentingnya keluarga sebagai faktor yang memberi pengaruh terhadap minat berwirausaha siswa. Pola pikir positif terhadap kewirausahaan perlu dibentuk sejak anak masih berusia dini agar minatnya terhadap kewirausahaan semakin besar dan mantap. Selain itu juga didukung oleh keluarga yang sukses wirausaha di bidang pertanian akan menguatkan minat anak berwirausaha dalam bidang pertanian.

\section{KESIMPULAN}

Berdasarkan hasil analisis data dan pembahasan, dapat disimpulkan:

1. Potensi kepribadian wirausaha berpengaruh positif dan signifikan terhadap minat berwirausaha siswa SMK Rumpun Pertanian di Daerah Istimewa Yogyakarta.

2. Pengetahuan kewirausahaan berpengaruh positif dan signifikan terhadap minat berwirausaha siswa SMK Rumpun Pertanian di Daerah Istimewa Yogyakarta.

3. Lingkungan keluarga berpengaruh positif dan signifikan terhadap minat berwirausaha siswa SMK Rumpun Pertanian di Daerah Istimewa Yogyakarta.

4. Potensi kepribadian wirausaha, pengetahuan kewirausahaan, dan lingkungan keluarga secara bersama-sama berpengaruh positif dan signifikan terhadap minat berwirausaha siswa SMK Rumpun Pertanian di Daerah Istimewa Yogyakarta.

\section{SARAN}

Minat berwirausaha yang dimiliki oleh siswa hendaknya dapat lebih ditingkatkan oleh semua pihak, orang tua, masyarakat, pendidik, maupun pemerintah. Penanaman nilai-nilai potensi kepribadian ditingkatkan dengan cara mengintegrasikan nilai-nilai percaya diri, kreativitas, keberanian mengambil resiko, berorientasi pada hasil, kepemimpinan, dan kerja keras dalam setiap mata pelajaran di sekolah dan dapat dilakukan dalam lingkungan keluarga sejak anak masih usia dini. Selain tu, perlu adanya pembelajaran kewirausahaan yang berorientasi pada praktek, studi kasus, dan mendatangkan nara sumber dari dunia usaha dan dunia industri, Adanya praktek industri sesuai 
program keahlian siswa juga dapat menambah pengetahuan dan wawasan siswa dimana siswa belajar sambil melakukan aktivitas pekerjaan dalam situasi sebenarnya.

\section{UCAPAN TERIMAKASIH}

Ucapan terima kasih yang setulusnya dan penghargaan disampaikan kepada yang terhormat:

1. Rektor Universitas Negeri Yogyakarta dan Direktur Program Pascasarjana Universitas Negeri Yogyakarta beserta staf.

2. Kaprodi Pendidikan Teknologi dan Kejuruan.

3. Prof. Dr. Aliyah A. Rasyid, pembimbing yang telah memberikan bimbingan, arahan, dan motivasi.

Kepala sekolah, guru-guru, dan staf SMK Negeri 1 Nanggulan Kulon Progo, SMK Negeri 1 Pandak Bantul, SMK Indonesia YIPK Bantul, dan SMK Perkebunan MM 52 Kota Yogyakarta.

\section{DAFTAR PUSTAKA}

Alma, Buchari. (2010). Kewirausahaan (edisi revisi). Bandung: CV Alfabeta.

Badan Pusat Statistik RI. (2011). Laporan Bulanan Data Sosial Ekonomi edisi Juni 2011. Jakarta: Badan Pusat Statistik.

Brown, Duane \& Brooks, Linda. (1990). Career Counseling Techniques. Boston: Allyn And Bacon.

Downey, W.D. \& Erickson, S.P. (1992). Manajemen Agribisnis. (Terjemahan Rochidayat Ganda \& Alfonsus Sirait). Jakarta: Penerbit Erlangga. (Buku Asli Agribusiness Management diterbitkan tahun 1987)
Hisrich, Robert D., Peters, Michael P., \& Shepherd, D.A. (2005). Entrepreneurship $\left(6^{\text {th }} e d\right)$. New York: The McGraw-Hill Companies Inc.

Kementrian Pendidikan Nasional (2010). Pengembangan Pendidikan

Kewirausahaan. Bahan Pelatihan:

Penguatan Metodologi Pembelajaran Berdasarkan Nilai-nilai Budaya untuk Membentuk Daya Saing dan Karakter Bangsa. Jakarta: Badan Penelitian dan Pengembangan Pusat Kurikulum, Kemendiknas.

Kuratko, D.F. \& Hodgetts, R.M. (2007). Entrepreneurship: Theory, Process, Practice $\left(7^{\text {th }} \mathrm{ed}\right)$. Canada: Interactive Composition Corporation.

Lambing, Peggy \& Kuehl, C.R. (2000). Entrepreneurship $\left(2^{\text {nd }}\right.$ ed $)$. New Jersey: Prentice-Hall, Inc.

Linan, Francisco \& Leon, J. A. M. (2007). Entrepreneurial Intentions. Department of Apply Economy I, Universidad de Sevilla. Department of Social and Organizational Psychology. UNED.

Mappiare, Andi. (1982). Psikologi Remaja. Surabaya: Usaha Nasional.

Mardapi, Djemari. (2004). Penyusunan Tes Hasil Belajar. Yogyakarta: Universitas Negeri Yogyakarta.

Minat Berwirausaha di Indonesia Rendah. (23 Maret 2011). Jawa Pos National Network. Diambil pada tanggal 7 Juli 2011, dari www.jpnn.com/read/ 2011/03/23/87627/

Saiman, Leonardus. (2009). Kewirausahaan. Teori, Praktik, dan Kasus-kasus. Jakarta. Salemba Empat.

Sarwono, Sarlito W.. (2011). Psikologi Remaja (edisi revisi). Jakarta: Rajawali Pers.

Timmons, Jeffry A. \& Spinelli, S., Jr. (2008). New Venture Creation. Kewirausahaan untuk Abad 21. Yogyakarta: Andi. (Buku asli New Venture Creation: Entrepreneurship for the $21^{\text {st }}$ Century $6^{\text {th }}$ ed.) 